\title{
Corrosion resistance studies on the concrete made with basalt fibres and basalt fibre reinforced rebars
}

\author{
E Giri Prasad Goud ${ }^{1 *}$, Marimuthu Kannimuthu ${ }^{2}$, V Srinivasa Reddy ${ }^{3}$, V Saikrishna ${ }^{4}$ \\ ${ }^{1}$ Research Scholar of Civil Engineering, K L University, Andhra Pradesh, India. \\ ${ }^{2}$ Department of Civil Engineering, K L University, Andhra Pradesh, India \\ ${ }^{3}$ Professor of Civil Engineering, GRIET, Hyderabad, Telangana, India. \\ ${ }^{4}$ M.Tech. (Structural Engineering), Department of Civil Engineering, GRIET, Hyderabad, India
}

\begin{abstract}
In the present work, assessment of corrosion resistance for M30 grade concrete made with basalt fibres in terms of Resistivity, Potentials and Chloride ion diffusion is made to understand the corrosion resistance studies of concrete specimen made with basalt fibre and BFRP bars. The time of total charge passing till full crack failure for different effective covers considered is more for M30 grade concrete beams made with basalt fibres and BFRP rebars. The time of total charge passing at failure in M30 grade concrete beams made with basalt fibres and BFRP rebars is more because beam specimens did not develop any fissures or micro cracks. Measured electrical resistivity values of M30 grade concrete beams made with basalt fibres have shown high electrical resistance indicating their superior corrosion inhibition ability. M30 grade concrete beams made with basalt fibres and BFRP rebars used for the study exhibited very less probability (less than $5 \%$ probability) for corrosion at 28 days.
\end{abstract}

\section{Introduction}

Corrosion is major issue in reinforced concrete structure made with steel rebars. So there are various mechanisms using which the corrosion in reinforced concrete structures can be prevented. Basalt fibre are obtained from basalt rock so no corrosion can occur in basalt fibres. Basalt fibre reinforced polymer bars are made from the basalt fibres and glued into the form of bars using polymer as glue. So, in this current study, concrete specimens are prepared with basalt fibres and basalt bar embedded at the centre and various corrosion presence studies are carried out.

\section{Methodology}

For this study, basalt fibre length of $36 \mathrm{~mm}$ and dosage of $0.4 \%$ fibre volume of the concrete is considered as optimum based on previous studies and is used for further studies. M30 grade concrete samples are made with basalt fibres and basalt fibre reinforced polymer (BFRP) bars. The mix proportion is mentioned below.
Table 1. Quantities per $\mathrm{m}^{3}$ of concrete for M30 grade concrete

\begin{tabular}{|c|c|c|c|c|}
\hline \multirow{2}{*}{$\begin{array}{c}\text { Concrete } \\
\text { grade }\end{array}$} & \multirow{2}{*}{$\begin{array}{c}\text { Cement } \\
\left(\mathrm{kg} / \mathrm{m}^{3}\right)\end{array}$} & \multirow{2}{*}{$\begin{array}{c}\text { Water } \\
(\mathrm{ltrs})\end{array}$} & $\begin{array}{c}\text { Fine } \\
\left(\mathrm{kg} / \mathrm{m}^{3}\right)\end{array}$ & $\begin{array}{c}\text { Coarse } \\
\left(\mathrm{kg} / \mathrm{m}^{3}\right)\end{array}$ \\
\hline M30 & 373 & 184 & 697.6 & 1149 \\
\hline
\end{tabular}

Ratio of ingredients of concrete for M30 grade concrete is 1: $1.86: 3.07$

In this study, assessment of corrosion resistance for M30 grade concrete made with basalt fibres in terms of Resistivity, Potentials and Chloride ion diffusion is made to understand the corrosion resistance studies of concrete specimen made with basalt fibre and BFRP bars.

\section{Corrosion Studies}

\subsection{Modified method of constant voltage technique}

*Corresponding author: giriprasadgoud7@gmail.com 
After 28 days of typical curing, four beams were cast and evaluated. All four corners of each beam are reinforced with $10 \mathrm{~mm}$ diameter HYSD bar with varied effective covers ranging from $10 \mathrm{~mm}$ to $40 \mathrm{~mm}$. Beams measuring $150 \mathrm{x} 150$ x $500 \mathrm{~mm}$ are cast and cured in fresh water for 28 days. The findings of a modified constant voltage methodology appropriate for accelerated cracking investigations in beams with $10 \mathrm{~mm}$ diameter HYSD bar reinforcement at varied effective covers ranging from $10 \mathrm{~mm}$ to $40 \mathrm{~mm}$ at all four corners of each beam are presented in this study. The specimens to be analysed are stored in a glass tub that measures $750 \mathrm{~mm}$ X $300 \mathrm{~mm}$ X $300 \mathrm{~mm}$ and is filled with real sea water. All of the extended reinforcements have been cleaned, sleeved, and are ready for the power supply units to be connected. The power supply is linked in parallel to all four bars, and anodic current is impressed at a constant voltage of $20 \mathrm{~V}$. The potentials for all the bars are recorded every 12 hours with reference to a freely corroding zinc electrode before and after an hour, and immediately before the test is closed for the day. The crack's length is measured and the work is terminated when it reaches $500 \mathrm{~mm}$.
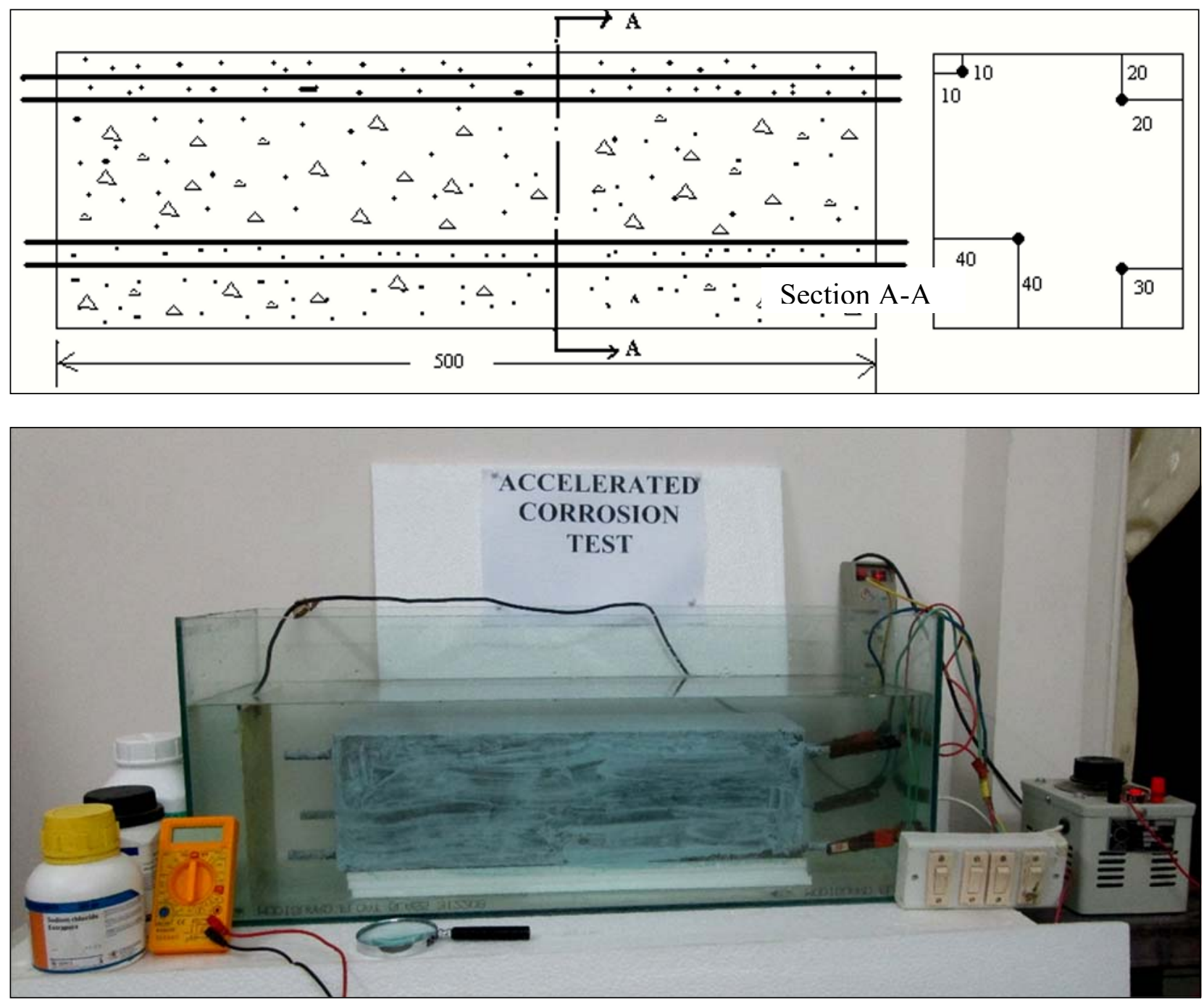

Fig.2. Accelerated corrosion of concrete set up 

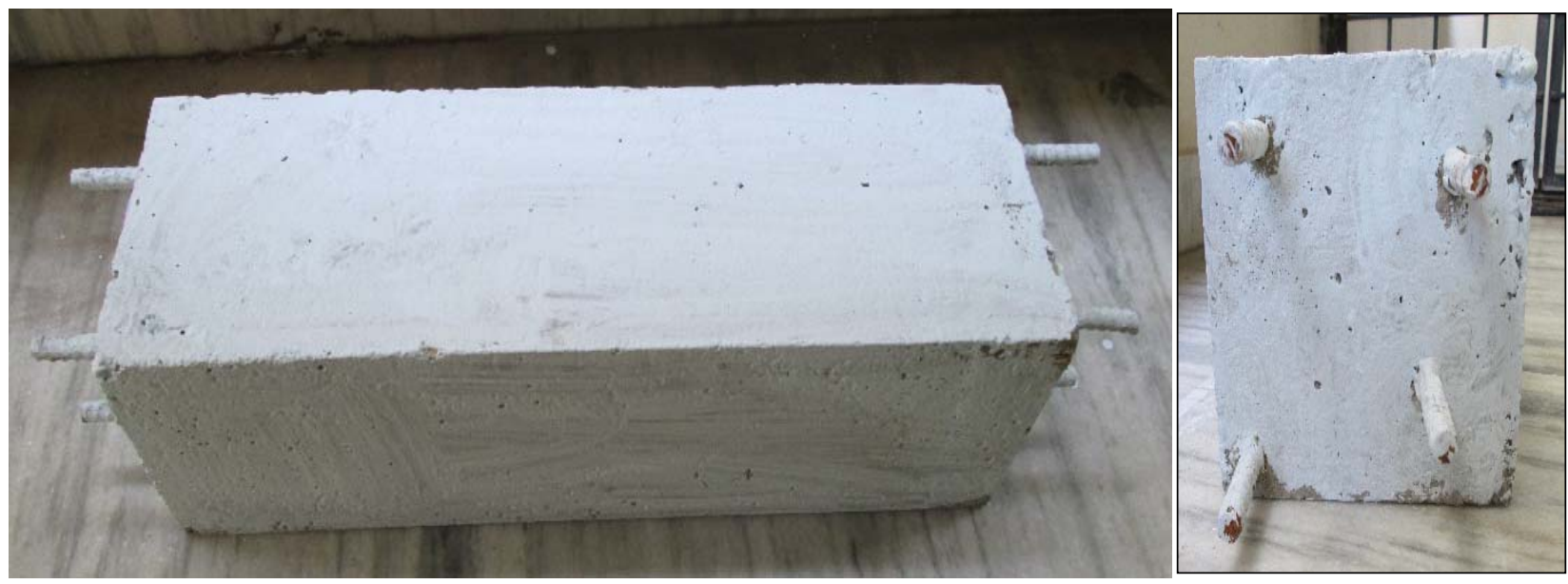

Fig.3. Test Specimen and Mould

The investigation is carried out to study the corrosion resistance for M30 grade concrete made with basalt fibres and BFRP bars. Beam Designations are shown below:

Beam- Type 1 = M30 grade concrete made with No fibres and steel rebars

Beam- Type $2=$ M30 grade concrete made with basalt fibres and steel rebars

Beam- Type 3 = M30 grade concrete made with No fibres and BFRP rebars

Beam- Type $4=$ M30 grade concrete made with basalt fibres and BFRP rebars

Table 2. Charge applied on each Beam (until full crack occur longitudinally)

\begin{tabular}{|c|c|c|c|c|}
\hline \multirow{2}{*}{ Beam Designation } & \multicolumn{3}{|c|}{ Time of total charge passed for full crack to occur longitudinally } \\
& \multicolumn{4}{|c|}{ (in Hours) } \\
\cline { 2 - 5 } & $10 \mathrm{~mm}$ & $20 \mathrm{~mm}$ & $30 \mathrm{~mm}$ & $40 \mathrm{~mm}$ \\
\hline Beam - Type 1 & 49 & 117 & 212 & 456 \\
\hline Beam - Type 2 & 31 & 81 & 160 & 342 \\
\hline Beam - Type 3 & 28 & 68 & 139 & 299 \\
\hline Beam - Type 4 & 36 & 94 & 188 & 389 \\
\hline
\end{tabular}

\subsection{Electrical resistivity studies}

The electrical resistivity technique is a nondestructive testing (NDT) method that determines the capacity of a medium to conduct electric current based on the presence of electrolyte, water, and salts in the concrete's pore solution.
The electrical resistance of the cube's saturated surface is measured. Resistivity $(\Omega \mathrm{cm}), \rho=(R * A) / L$

Where

$\mathrm{R}=$ Resistance measured in kilo ohms

$\mathrm{A}=$ Surface area of the cube $=100 \mathrm{~cm}^{2}$

$\mathrm{L}=$ Distance between two electrodes $=10 \mathrm{~cm}$ 

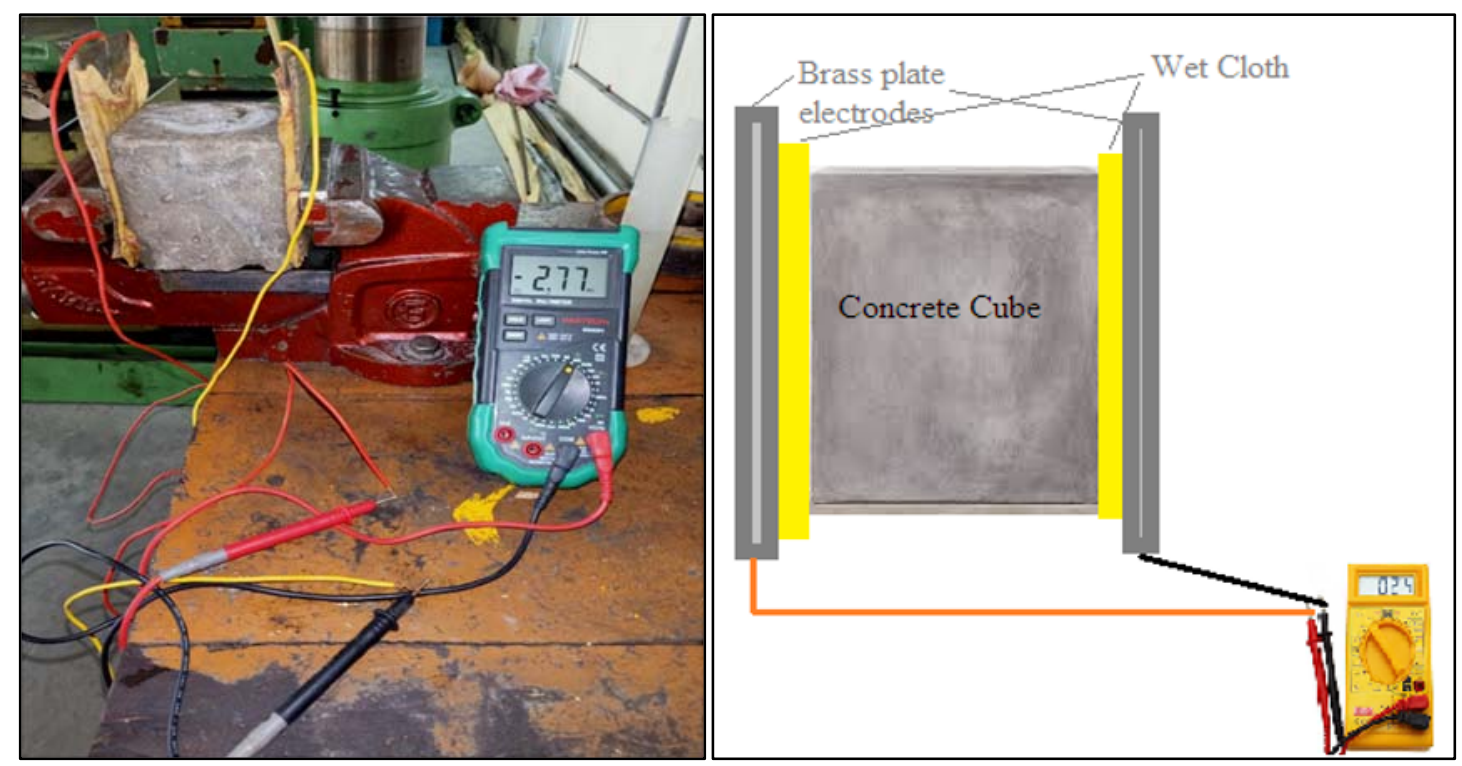

Fig.4. Experimental setup for measuring the electrical resistivity

Table 3. Electrical Resistivity of M30 grade concrete made with basalt fibres

\begin{tabular}{|c|c|c|c|c|}
\hline \multirow{2}{*}{} & \multicolumn{3}{|c|}{ Resistivity $\rho(\Omega . c m)$} \\
\cline { 2 - 4 } & 3 days & 7 days & 14 days & 28 days \\
\hline Type 1 & 6800 & 16900 & 31650 & 58900 \\
\hline Type 2 & 14200 & 24500 & 36000 & 69500 \\
\hline Type 3 & 14300 & 25000 & 54900 & 85300 \\
\hline Type 4 & 11300 & 21800 & 54700 & 79500 \\
\hline
\end{tabular}

\subsection{Half-cell potentiometer Test}

Measuring half-cell potentials in M30 grade concrete with basalt fibres and BFRP rebars to predict the likely rate of corrosion.

ASTM C 876 suggests a criteria for evaluating the probability of corrosion based on potentials (SCE, $\mathrm{mV}$ ).
According to it, if the potentials is more than -120 , the probability of corrosion is as low as $5 \%$, if the potentials is between -120 and -270 , the probability of corrosion is nearly $50 \%$, and if the potentials is less than -270 , the probability of corrosion is as high as $95 \%$. Half-cell potentials of M30 grade concrete produced with basalt fibres and BFRP rebars are shown in the tables. 


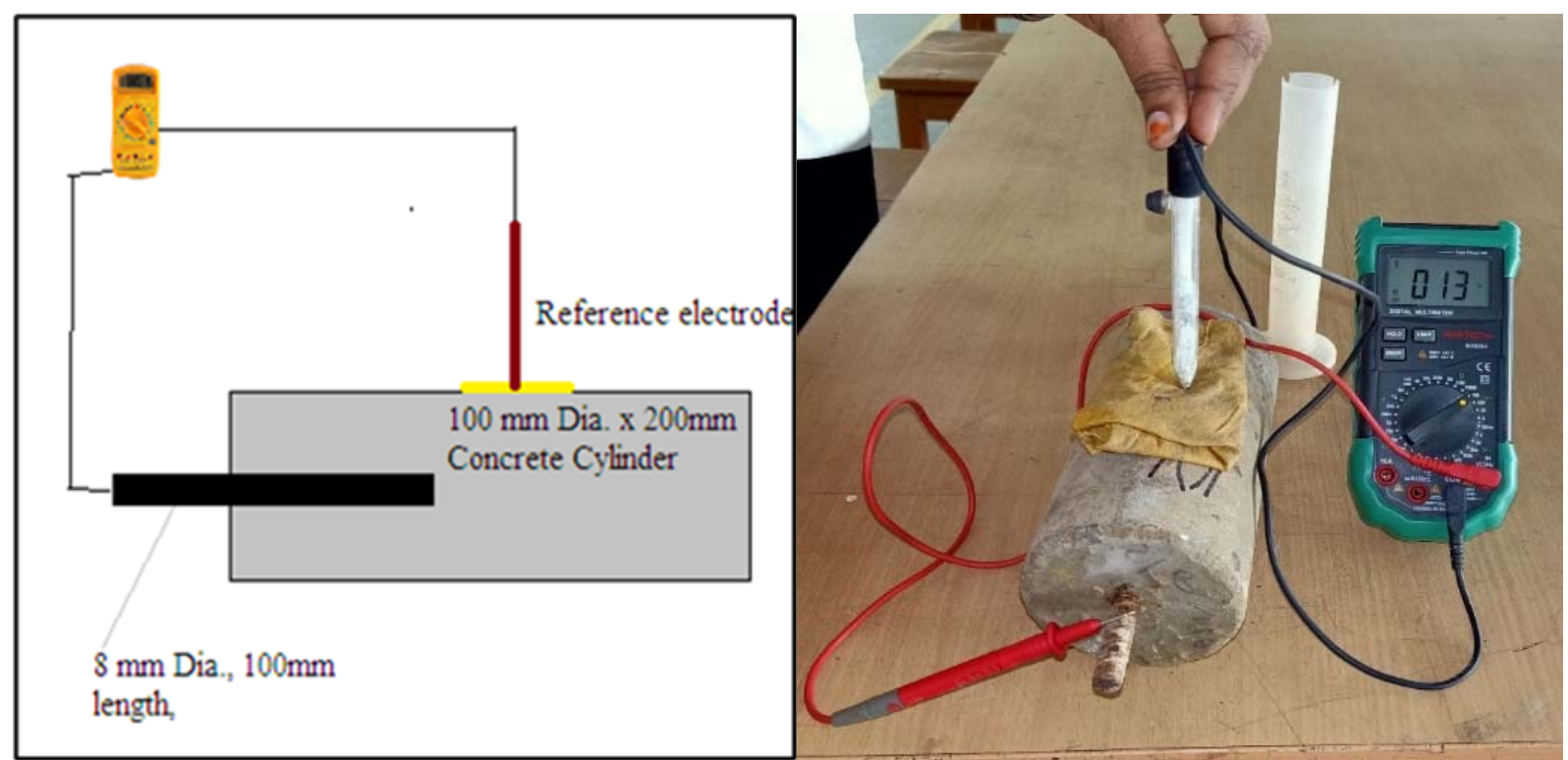

Fig.5. Half-cell potentiometer Test setup

Table 4. Potentials of M30 grade concrete made with basalt fibres and BFRP rebars

\begin{tabular}{|c|c|c|c|c|}
\hline \multirow{2}{*}{} & \multicolumn{4}{|c|}{ Potential (-mV) } \\
\cline { 2 - 5 } & 3 days & 7 days & 14 days & 28 days \\
\hline Type 1 & No Reading & 176 & 98 & 47 \\
\hline Type 2 & No Reading & 142 & 94 & 45 \\
\hline Type 3 & No Reading & 134 & 54 & 33 \\
\hline Type 4 & No Reading & 126 & 45 & 17 \\
\hline
\end{tabular}

If half-cell potentials are high (more negative value, i.e. $>$ $270 \mathrm{mV}$ ), the likelihood of corrosion is considerable; otherwise, if half-cell potentials are low (less negative value, i.e. $-120 \mathrm{mV}$ ), the likelihood of corrosion is extremely low. Corrosion is more likely to start in M30 grade concrete beams containing basalt fibres and BFRP rebars.

\section{Conclusions}

1. For M30 grade concrete beams constructed with basalt fibres and BFRP rebars, the time from entire charge passage to full crack failure is longer for different effective coverings evaluated.

2. Because the beam specimens did not develop any fissures or micro fractures, the period of complete charge passage at failure in M30 grade concrete beams constructed with basalt fibres and BFRP rebars is longer.

3. Electrical resistivity values of M30 grade concrete beams constructed with basalt fibres were found to be high, indicating that they had better corrosion prevention capacity.

4. The M30 grade concrete beams with basalt fibres and BFRP rebars employed in the study had a very low chance of corrosion (less than $5 \%$ probability) after 28 days.

\section{References}

1. T.Srinivas and M. Abinay Raj, Int. J. of Eng.and Adv. Tech. (IJEAT), ISSN: 2249 - 8958, Volume-8 Issue-6 (August-2019), PP 4662-4666.

2. T.srinivas and P. Manoj Anand, Int. J. of Innov. Tech. and Explor. Eng.g (IJITEE), ISSN: 2278-3075, Volume-8 Issue-12 (October-2019), PP 2987-2990.

3. T.Srinivas and G. Sukesh Reddy, Int. J. of Eng.and Adv. Tech. (IJEAT), ISSN: 2249 - 8958, Volume-9 Issue-1 (October-2019), PP 2301-2304.

4. Srinivas Rao J, S K Tummala, Kuthuri N R, Indonesia Journal of Electrical Engg. \& Computer Science, 21 (723), 2020

5. T.Srinivas and R. N. Koushik, Int. J. of Innov. Tech. and Explor. Eng.g (IJITEE), ISSN: 2278-3075, Volume-8 Issue-12 (October-2019), PP 112-117.

6. K. Sai Gopi, Dr. T. Srinivas and S. P. Raju V, E3S Web of Conferences ICMED 184, 01084(2020), GRIET, 2829 https://doi.org/10.1051/e3sconf/2020184011084 
7. Jagannadha Kumar, M.V., Jagannadha Rao, K., Dean Kumar, B., Srinivasa Reddy, V., Int. J. of Civil Eng. and Tech., 9(7), pp. 1133-1141, 2018

8. Ganta, J.K., Seshagiri Rao, M.V., Mousavi, S.S., Srinivasa Reddy, V., Bhojaraju, C., Structures 28, pp. 956-972, 2020

9. Naidu, K.S.S.T., Rao, M.V.S., Reddy, V.S., Int. J. of Innov. Tech. and Explor. Eng.g (IJITEE), 8(9 Special Issue 2), pp. 641-642, 2019

10. Chandana Priya, C., Seshagiri Rao, M.V., Srinivasa Reddy, V., Int. J. of Civil Eng. and Tech., 9(11), pp. 2218-2225, 2018

11. Satya Sai Trimurty Naidu, K., Seshagiri Rao, M.V., Srinivasa Reddy, V., Int. J. of Civil Eng. and Tech., 9(11), pp. 2383-2393, 2018

12. B. J. Varghese, P. B. Bobba and M. Kavitha, 2016 IEEE 7th Power India International Conference (PIICON), 2016, pp. 1-6

13. Supriya, Y., Srinivasa Reddy, V., Seshagiri Rao, M.V., Shrihari, S., Int. J. of Rec. Tech. and Engi., 8(3), pp. 5381-5385, 2019

14. Kotkunde, N., Krishna, G., Shenoy, S.K., Gupta, A.K.,
Singh, S.K. International Journal of Material Forming, 10 (2), pp. 255-266 (2017)

15. Govardhan, D., Kumar, A.C.S., Murti, K.G.K., Madhusudhan Reddy, G. Materials and Design, 36, pp. 206-214. (2012)

16. Kumar, P., Singhal, A., Mehta, S., Mittal, A. Journal of Real-Time Image Processing, 11 (1), pp. 93-109. (2016)

17. Raghunadha Reddy, T., Vishnu Vardhan, B., Vijayapal Reddy, P. International Journal of Applied Engineering Research, 11 (5), pp. 3092-3102 (2016)

18. M. Kavitha, P. B. Bobba and D. Prasad, 2016 IEEE 6th International Conference on Power Systems (ICPS), 2016, pp. 1-6

19. Hussaini, S.M., Krishna, G., Gupta, A.K., Singh, S.K. Journal of Manufacturing Processes, 18, pp. 151-158 (2015)

20. K. D. Rajesh, T. Buddi, P.R. Kanth, and K. Satyanarayana, Advances in Materials and Processing Technologies, 6(2), 189 (2020) 